\begin{tabular}{c}
\hline TÜRK \\
TARIM ve DOĞA BILIMLERI \\
DERGISI \\
\hline \hline
\end{tabular}

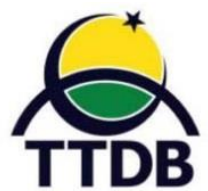

www.dergipark.gov.tr/turkjans

Araştırma Makalesi

\title{
Portakal Kabuğu Yağı ve Nar Çekirdeği Yağı ile Zenginleştirilen Diyetlerin Bıldırcınların Verim Performansı, Yumurta Kalitesi ve Bazı Kan Parametreleri Üzerine Etkileri\&
}

\author{
Şebnem SELÇUK ${ }^{1}$, Turgay ŞENGÜL ${ }^{2}$ \\ ${ }^{1}$ Bingöl Üniversitesi Fen Bilimleri Enstitüsü Zootekni ABD-Bingöl \\ ${ }^{2}$ Bingöl Üniversitesi Ziraat Fakültesi Zootekni Bölümü-Bingöl \\ Sorumlu yazar:tsengul2001@yahoo.com
}

Geliş Tarihi: 19.03.2021 Düzeltme Geliş Tarihi: 17.05.2021 Kabul Tarihi: 30.06.2021

\section{Öz}

Bu çalışma, bıldırcınların diyetlerine ilave edilen portakal kabuğu yağı (PKY) ve nar çekirdeği yağının (NÇY), bıldırcınlarda, canlı ağırlık, yem tüketimi, yemden yararlanma oranı, yumurta verimi, yumurta kalitesi, yumurta sarısı yağ içeriği ve yağ asidi kompozisyonu, oksidatif stres ve bazı kan parametreleri üzerine etkilerini ortaya koymak amacıyla yapılmıştır. Çalışmada, diyetlere 2 farklı düzeyde (0.5 ve $1 \mathrm{~g} / \mathrm{kg}$ ) PKY ve NÇY ilave edilmiştir. Her biri 3 tekerrürlü olmak üzere, kontrol, $0.5 \mathrm{~g} / \mathrm{kg}$ PKY, $1 \mathrm{~g} / \mathrm{kg}$ PKY, $0.5 \mathrm{~g} / \mathrm{kg}$ NÇY ve $1 \mathrm{~g} / \mathrm{kg}$ NÇY olmak üzere toplam 5 grup teşkil edilmiştir. Denemede, 8 haftalık yaşta 180 adet dişi bıldırcın kullanılmıştır. Bıldırcınlar, deneme süresince $\% 20$ ham protein ve $3000 \mathrm{kcal} / \mathrm{kg} \mathrm{ME}$ içeren diyetlerle serbest olarak yemlenmişlerdir. Elde edilen sonuçlara göre, diyete yapılan PKY ve NÇY katkılarının, verim performansı, yumurta kalitesi ve kan parametreleri üzerine önemli olumsuz etkileri görülmemiştir. Buna karşııı, yumurta verimi, yumurta ağırlığı, kabuk kalınlığı, sarı ağırlı̆̆ı, sarı rengi, HDL, AST, LDH, MDA ve yumurta sarısı kolesterol düzeyi gibi özellikler bakımından dikkati çeken iyileşmeler gözlenmiştir. Oksidatif stres hasarını gösteren MDA, tüm muamele gruplarının yumurta sarılarında önemli oranda düşüş göstermiştir. Yem katkıları, palmitik asit, stearik asit ve miristik asit gibi doymuş yağ asitlerinin düzeylerinde önemli azalmaya; oleik asit, gama linoleik asit, heptadekanoik asit gibi yağ asitlerinde ise artışa neden olmuştur. Kontrol grubuna oranla, muamele gruplarının doymuş yağ asitleri düzeyinde önemli azalmalar, PUFA/SFA oranında ise önemli artışlar görülmesi, her iki yem katkısının da özellikle yumurtanın besleme değeri açısından yararlı etkilerini göstermesi bakımından önemlidir.

Anahtar kelimeler: Bıldırcın, portakal kabuğu yağı, nar çekirdeği yağı, verim peformansı, yumurta kalitesi, yağ asitleri, kan parametreleri

\section{Effects of Diets Enriched with Orange Peel Oil and Pomegranate Seed Oil on Yield Performance, Egg Quality and Some Blood Parameters of Quails}

\begin{abstract}
The aim of this study was to investigate the effects of orange peel oil (OPO) and pomegranate seed oil (PSO) added to the diets of laying quails on live weight, feed consumption, feed conversion ratio, egg yield, egg quality, egg yolk crude fat content, egg yolk fatty acid composition, oxidative stress and some blood parameters. In the study, orange peel oil and pomegranate seed oil were added at two different levels $(0.5$ and $1 \mathrm{~g} / \mathrm{kg})$, respectively. Five treatment groups, each with 3 replicates were prepared, consisting of control, $0.5 \mathrm{~g} / \mathrm{kg}$ orange peel oil, $1 \mathrm{~g} / \mathrm{kg}$ orange peel oil, $0.5 \mathrm{~g} / \mathrm{kg}$ pomegranate seed oil and $1 \mathrm{~g} / \mathrm{kg}$ pomegranate seed oil. A total of 180 female quails were used in the experiment. Experimental groups were fed with 5 different diets prepared with $20 \% \mathrm{HP}$ and $3000 \mathrm{kcal} / \mathrm{kg} \mathrm{ME}$
\end{abstract}


throughout the laying period. According to the results, there was no significant effect of OPO and PSO additives on the diet on yield performance, egg quality and blood parameters. On the other hand, significant improvements were observed in properties such as egg production, egg weight, shell thickness, yolk weight, yolk color, and HDL, AST, LDH, MDA and yolk cholesterol level. Malondialdehyde (MDA), a lipid peroxidation product, is known to be an important predictor of oxidative stress. It decreased significantly in egg yolks of all treatment groups. Feed additives significantly reduce the levels of saturated fatty acids such as palmitic acid, stearic acid and myristic acid; it caused an increase in fatty acids such as oleic acid, gamma linoleic acid, heptadecanoic acid. Compared to the control group, the saturated fatty acids of the treatment groups significantly decreased, and the PUFA/SFA ratios were significant, it is important that its two feed additives show beneficial content, especially regarding the content of the egg.

Keywords: Quail, orange peel oil, pomegranate seed oil, productive performance, egg quality, fatty acids, blood parameters

\section{Giriş}

Fitokimyasal bileşikler, bitkilerin kendilerine has tat, koku ve renklerinin oluşumunu sağlayan biyolojik aktif bileşiklerdir. $\mathrm{Bu}$ bileşikler, antioksidan özellikte olup, hücrelerin doğal oksidasyon reaksiyonlarının sonucunda ortaya çıkan serbest radikallerin yıkımlayıcı etkilerine karşı koruyucu görev yapmaktadırlar. Fitokimyasal bileşikler, tek başına besin özelliği taşımayan fakat vücut savunmasında koruyucu etki yapan birçok biyoaktif bileşikleri de içermektedir (Dündar, 2001). Son yıllarda, antioksidan içeriği yüksek fitokimyasal bileşiklerden olan portakal kabuğu yağı ve nar çekirdeği yağı hayvan besleme çalışmalarında kullanılmaya başlanmıştır. Söz konusu esansiyel yağların, yem katkı maddesi olarak kanatlı hayvanların diyetlerinde kullanıldığında bazı verim özellikleri üzerine olumlu etkiler yaptığı bildirilmiştir (Bölükbaşı ve ark., 2010; Ting ve ark., 2011; Liu ve ark., 2013; Atılgan, 2012; Yassein ve ark., 2015). Portakal kabuğu yağı ve nar çekirdeği yağının yüksek antioksidan içeriğine sahip olduğu ve bağırsaktan kolesterol emilimini azalttığı açıklanmıştır (Turhan ve ark., 2006; Sarıca, 2011; Hegazy ve İbrahim, 2012). Portakal kabuğu, flavedo ve albedo olarak adlandırılan iki katmandan oluşmaktadır. Bu katmanlardan en dıştaki meyveye rengini veren ve karotenoid pigmentleri ihtiva eden tabakaya flavedo, içteki beyaz renkli, besin maddeleri, pektin ve suyu taşıyan damarlardan oluşan tabakaya da albedo adı verilmektedir. Portakal kabuğu yağı, flavedo tabakasındaki keselerde bulunan yağ hücrelerinden elde edilmektedir (Turhan ve ark., 2006). Portakal kabuğundan elde edilen esansiyel yağ, 200 farklı komponentin bir karışımı durumundadır ve bir bütün meyve kabuğunun \%1.48'ini teşkil etmektedir
(Kamaliroosta ve ark., 2016). Portakal kabuğu, karotenoidler, glikozinolatlar, fitosteroller, saponinler, fitoöstrojenler, flavonlar ve proteaz inhibitörlerini bol miktarda içermektedir. Portakal kabuğunun yapısında bulunan flavonoidler, mikrozomal lipit peroksidasyon reaksiyonlarını önleyerek dokularda serbest radikallerin oluşumunun önüne geçerler. Ayrıca, etkisini gösterebilmesi için bağırsak bariyerinden geçmeleri gerekmediğinden, bağırsaklarda yüksek konsantrasyonlarda bulunabilirler ve bağırsak florası üzerinde de etki gösterebilmektedirler (Güven ve ark., 2010; Bayrakdar ve ark., 2017). Yine, kabuğun yapısında bulunan terpenler peroksidasyonun ve dokulardaki oksidatif stresin önüne geçen antioksidan özellikteki bileşiklerdir. Aynı zamanda enzim aktivitelerini kontrol eden, nitrozaminlerin oluşumuna engel olan ve kan lipit düzeylerindeki dengesizliklerin giderilmesini sağlayan fenolik maddeler de portakal kabuğunun yapısında bulunmaktadır (Dündar, 2001). Bunun yanı sıra, portakal kabuğunda bulunan yağ, değerli fitokimyasallardan olan d-limonen, hesperetin ve naringenin gibi aktif komponentleri de zengin bir biçimde içermektedir. Portakal meyvesinin kabuk oranı yaklaşık \%15'dir (Yaman, 2012). Portakal kabuğu yağı, portakal kabuğunun portakala rengini veren en dıştaki kısmından elde edilmektedir. Portakal kabuğu yağı, üzerinde iğneler bulunan titreşimli valslerden oluşan makinelerden portakalların geçirilmesi veya portakal kabuğunun üst tabakası olan flavedonun rendelenmesi ve elde edilen kabuğun preslenmesi ile ayrılmaktadır. Her iki yöntemde de elde edilen yağ-su karışımı uygun separatörlerden geçirilerek portakal kabuğu yağı elde edilmektedir. Rendeleme ve 
ardından presleme sonucu alınan kabuk yağına soğuk preslenmiş yağ adı verilmektedir. Portakalda kabuk yağı verimi, portakal çeşidine göre değişmekte olup, genellikle 0.45-3.6 $\mathrm{kg} /$ ton arasındadır (Turhan ve ark., 2006). Nar, Punicaceae familyasının bir üyesi olup, anavatanı Kapadokya, İran, Afganistan, Ortadoğu ve Hicaz olan en eski meyve türlerindendir. Narın toplam ağırlığının ortalama \%48'i kabuktan, \%52'si meyveden oluşurken, yenilebilen kısmın \%78'i nar suyundan, \%22'si ise çekirdekten oluşmaktadır (Sarıca, 2011). Nar çekirdeği yağı, toplam çekirdek ağırlığının \%12-20'si kadardır. Bu yağın önemli bir kısmını (yaklaşık \%31.8-86.6) konjuge linoleik asit oluşturmaktadır. Bunu, sırasıyla, linoleik asit (\%0.7-24.4), oleik asit (0.4-17.7), stearik asit (2.8-16.7) ve palmitik asit (\%0.3-9.9) izlemektedir (El-Shaarawy ve Nahapetian, 1983; Özgül-Yücel, 2005; Fadavi ve ark., 2006). Konsantrasyonlardaki değişkenlikler çeşit farklılıklarından kaynaklanmaktadır. Nar çekirdeği yağındaki konjuge linoleik asitin tümü 9,11,13 izomerleri olup, baskın konjuge trien punisik asittir (9 cis, 11 trans, 13 cis) (ÖzgülYücel, 2005; De Melo ve ark., 2014) . Narın farklı kısımları farklı potansiyel biyolojik aktiviteye sahip komponentler içermektedir.
Nar kabuğu ve meyvesinin diğer anatomik kısımlarında toplam 48 farklı fenolik komponentin bulunduğu tespit edilmiştir. Meyvedeki antosiyanidinlerin \%30'u kabukta konsantre olmuş durumdadır (Mansour ve ark., 2013; Anonim, 2014; Akhtar ve ark., 2015; Sharmin ve ark., 2016). Nar çekirdeğindeki polifenollerden olan kondanse tanenler veya proantosiyanidinler kolesterolün taşınması ve safra asidi atılımını artırarak, kolesterolün bağırsaktan emilimini azaltmaktadır (Sarıca, 2011; Padmaja ve Prasad, 2011; Akhtar ve ark., 2015). Ayrıca, nar çekirdeği yağındaki elajik asit antioksidan savunma aktivitesini artırarak hücre DNA'sının zarar görmesini zorlaştırmaktadır. Bunun yanı sıra, elajik asit kas hücresi sarkoplazmik retikulumunda kalsiyum salınımında etkili olmaktadır (Dündar, 2001). Nar çekirdeği yağı, bu ve daha bir çok önemli yararları nedeniyle son yıllarda ticari olarak artan miktarlarda üretilmekte ve pazarlanmaktadır (Meerts ve ark., 2009).

$\mathrm{Bu} \quad$ çalışmada, yumurtlayan bıldırcınların diyetlerine farklı düzeylerde katılan portakal kabuğu yağı ve nar çekirdeği yağının bıldırcınların verim özellikleri, yumurta kalitesi, yumurtanın besin madde içeriği ve bazı kan parametreleri üzerine etkileri araştırılmıştır.

Çizelge 1. Denemede kullanılan rasyonlar ve bunların analiz edilmiş değerleri.

\begin{tabular}{|c|c|c|c|c|c|}
\hline Yem Hammaddeleri & Kontrol & $0.5 \mathrm{~g} / \mathrm{kg}$ PKY & $1 \mathrm{~g} / \mathrm{kg}$ PKY & $0.5 \mathrm{~g} / \mathrm{kg} \mathrm{NÇY}$ & $1 \mathrm{~g} / \mathrm{kg} \mathrm{NÇY}$ \\
\hline Misır & 53.50 & 53.00 & 53.00 & 53.00 & 53.00 \\
\hline SFK (44 HP) & 31.97 & 31.97 & 31.97 & 31.97 & 31.97 \\
\hline Bitkisel yağ & 4.47 & 4.47 & 4.47 & 4.47 & 4.47 \\
\hline Mermer tozu & 6.67 & 6.67 & 6.17 & 6.67 & 6.17 \\
\hline DCP & 1.76 & 1.76 & 1.76 & 1.76 & 1.76 \\
\hline Metiyonin & 0.98 & 0.98 & 0.98 & 0.98 & 0.98 \\
\hline Lisin & 0.20 & 0.20 & 0.20 & 0.20 & 0.20 \\
\hline Tuz & 0.20 & 0.20 & 0.20 & 0.20 & 0.20 \\
\hline Vit-Min premiks & 0.25 & 0.25 & 0.25 & 0.25 & 0.25 \\
\hline PKY $(0.5 \mathrm{~g} / \mathrm{kg})$ & 0 & 0.5 & 0 & 0 & 0 \\
\hline PKY $(1 \mathrm{~g} / \mathrm{kg})$ & 0 & 0 & 1 & 0 & 0 \\
\hline $\mathrm{NÇY}(0.5 \mathrm{~g} / \mathrm{kg})$ & 0 & 0 & 0 & 0.5 & 0 \\
\hline NÇY (1 g/kg) & 0 & 0 & 0 & 0 & 1 \\
\hline \multirow[t]{2}{*}{ Toplam } & 100 & 100 & 100 & 100 & 100 \\
\hline & \multicolumn{5}{|c|}{ Analiz edilmiş değerler } \\
\hline Ham protein (\%) & 20.00 & 20.00 & 20.00 & 20.00 & 20.00 \\
\hline ME (kcal/kg) & 2990 & 2990 & 2990 & 2990 & 2990 \\
\hline Kuru madde (\%) & 89.3 & 89.3 & 89.3 & 89.3 & 89.3 \\
\hline Yağ (\%) & 8.13 & 8.13 & 8.13 & 8.13 & 8.13 \\
\hline Selüloz (\%) & 1.83 & 1.83 & 1.83 & 1.83 & 1.83 \\
\hline Kül (\%) & 11.66 & 11.66 & 11.66 & 11.66 & 11.66 \\
\hline
\end{tabular}

DCP: Dikalsiyum fosfat, PKY: Portakal kabuğu yağı, NÇY: Nar çekirdeği yağı, ME: Metabolik enerji, Vit-+Min. premiksi $(2.5 \mathrm{~kg})$ : Vitamin A $12000000 \mathrm{IU}$, Vitamin $\mathrm{D}_{3} 2000000 \mathrm{IU}$, Vitamin E $35000 \mathrm{mg}$, Vitamin K $5000 \mathrm{IU}$, Vitamin $\mathrm{B}_{1} 3000$ $\mathrm{mg}$, Vitamin $B_{2} 6000 \mathrm{mg}$, Vitamin $B_{6} 5000 \mathrm{mg}$, Vitamin $B_{12} 15 \mathrm{mg}$, Vitamin C 50000 mg, D-Biotin $45 \mathrm{mg}$, Niasin 20000 mg, Ca D Pantotenat 6000 mg, Folik asit 750 mg, Kolin klorit 125000 mg, Mangan 80000 mg, Demir 60000 mg, Çinko $60000 \mathrm{mg}$, Bakır $5000 \mathrm{mg}$, Karotenoik asit etil ester $5.000 \mathrm{mg}$ (karofil ${ }^{\circledR}$ sarısı). 


\section{Materyal ve Yöntem}

Araştırmanın hayvan materyalini, 8 haftalık yaşta 180 adet dişi Japon bıldırcını (Coturnix coturnix japonica) oluşturmuştur. Çalışma, Bingöl Üniversitesi Ziraat Fakültesi Zootekni Bölümüne ait Araştırma ve Uygulama Çiftliği'ndeki pencereli bir kümeste yürütülmüştür. Deneme, 1 kontrol ve 4 muamele grubu olarak planlanmış ve 8 hafta süreyle yürütülmüştür. Deneme grupları; kontrol, $0.5 \mathrm{~g} / \mathrm{kg}$ portakal kabuğu yağı, $1 \mathrm{~g} / \mathrm{kg}$ portakal kabuğu yağı, $0.5 \mathrm{~g} / \mathrm{kg}$ nar çekirdeği yağı ve $1 \mathrm{~g} / \mathrm{kg}$ nar çekirdeği yağı olmak üzere toplam 5 grup şeklinde dizayn edilmiştir. Deneme gruplarına ait bıldırcınlar, deneme süresince \%20 HP ve $2990 \mathrm{kcal} / \mathrm{kg} \mathrm{ME}$ içeren yemle serbest olarak olarak beslenmiştir. Denemede kullanılan diyetler ve bunların analiz edilmiş değerleri Çizelge 1 'de verilmiştir.

Diyetlerde yem katkı maddeleri olarak kullanılan portakal kabuğu yağı ile nar çekirdeği yağı soğuk press yöntemi ile üretim yapan ticari bir firmadan temin edilmiştir. Denemede kullanılan bıldırcınlar, tüm deneme süresince plastikten imal edilen çok katlı kafeslere ait bölmelerde barındırılmışlardır. Aydınlatma programı, deneme süresince 16 saat aydınlık ve 8 saat karanlık olacak şekilde uygulanmıştır. Canlı ağırlıklar, denemenin ilk ve son haftasında olmak üzere iki kez ölçülmüştür. Yem tüketimi, yemden yararlanma oranı, yumurta verimi ve yumurta ağırlığı haftalık olarak belirlenmiştir. 9. ve 16. haftalarda, her gruptan 30'ar adet toplanan yumurtalarda kalite ölçümleri yapılmıştır. Yumurtalarda dış ve iç kalite özelliklerinden, yumurta ağırlığı, şekil indeksi, kabuk ağırlığı, kabuk kalınlığı, sarı ağırlığı, sarı indeksi, ak indeksi, haugh birimi ve sarı rengi ölçülmüştür. Tartımlar için 0,001 g hassasiyetle ölçüm yapan elektronik bir terazi, yumurtaların en ve boy ölçümleri için dijital kumpas kullanılmıştır. Yumurtanın sarı ve ak ölçümleri için yüzeyine cam yerleştirilmiş ve eğimi ayarlanmış bir masa ve kabuk kalınlığını ölçmek için de bu amaçla üretilmiş olan dijital bir mikrometre kullanılmıştır. Yumurtalar, 24 saat oda sıcaklığında bekletildikten sonra ölçümleri yapılmıştır. Yumurtalar önce tartılarak yumurta ağırlığı belirlenmiş ve daha sonra eni ve boyu ölçülmüştür. Yumurtalar daha sonra, hazırlanan masadaki camın üzerine kırılmış ve 10 dakika sonra sarı çapı, sarı yüksekliği, ak yüksekliği ve ak genişliği ölçümü yapılmıştır. Yumurtanın sarı ağırlığı, yumurta sarısının yumurta akından ayrılarak tartılmasıyla saptanmıştır. Kırılmış olan yumurta kabukları suda yıkanarak kalıntılardan temizlenmiş ve 24 saat oda sıcaklığında kurutulmuştur. Kuruyan kabuklar, kabuk zarları ile birlikte tartılarak ağırıkları saptanmıştır. Daha sonra yumurtanın sivri, küt ve orta kısımlarından olmak üzere üç farklı yerden alınan kabuk kalınlıkları dijital bir mikrometre ile ölçülmüş ve bu üç ölçümün ortalamasıyla kabuk kalınlığı tespit edilmiştir. Yapılan ölçümlerde aşağıdaki formüller kullanılarak gerekli hesaplamalar yapılmıştır.

Şekil indeksi = Yumurta genişliği/Yumurta uzunluğu $\times 100$

Ak indeksi $=[$ Ak yüksekliği $(\mathrm{mm}) /($ Ak uzunluğu $(\mathrm{mm})$ ve Ak genişliğinin ortalaması $(\mathrm{mm}))] \times 100$ Sarı indeksi $=($ Sarı yüksekliği/Sarı çapı $) \times 100$ Haugh Birimi $=100 \log \left(\mathrm{H}+7.57-1.7 \mathrm{G}^{0,37}\right)$ $\mathrm{H}$ : Ak yüksekliği (mm) G: Yumurta ağırlığı (g)

Yumurta sarısı rengi üç boyutlu olarak Renk Ölçüm Cihazı (Reflektans Tintometre Lovibond, İngiltere) ile renk eşleşmesi için evrensel bir şablon olan CIELAB renk uzay modeline göre ölçülmüş ve kantitatif renk birimleri olan $L$, $a$ ve $b$ değerleri tespit edilmiştir. Yumurta sarısında yağ oranı ve yağ asidi kompozisyonunu belirlemek üzere Folch ve ark., (1957) tarafından belirtilen metot kullanılmıştır. Yağ asidi analizinde Optima marka delta-6-0,25 $\mu \mathrm{m}$ (100 m×0,25 mm ID) kolon ve Agillent 7890A/5970C marka ve Gaz Kromatografi Kütle Spektrometri (GC-MS) cihazı ve FID dedektörü kullanılmıştır. Yumurta sarısı örneklerinde $A, D$ ve $E$ vitamin ve kolesterol analizi için Supelcosil LC 18 DB $(250 \times 4,6 \mathrm{~mm}$, Sigma, USA) kolonu ve HPCL cihazı (HPLC, Shimadzu LC 20A Series, Japonya) kullanılmıştır. Yumurta sarısı ve kan serumunda malondialdehit (MDA) analizi Dahle ve ark., (1962) yöntemine göre gerçekleştirilmiştir. Analizde MDA (tetraetoksipropan, MA:220,3; $\mathrm{d}=0,92$; \%96) standardı kullanılarak, spektrofotometreden alınan absorbans okumalarına göre çizilen kalibrasyon grafiğinin eğimi belirlenerek, örneklerdeki MDA konsantrasyonları ( $\mathrm{nmol} / \mathrm{g}, \quad \mathrm{nmol} / \mathrm{ml}$ ) hesaplanmıştır. Denemede kullanılan bıldırcınların kan parametrelerini analiz etmek üzere, deneme sonunda her gruptan 9'ar adet hayvan kesilmiş ve kanları, BD Vacutainer marka kanın pıhtılaşmasını sağlayan özellikteki 
sarı kapaklı serum separatör kan tüplerine alınmıştır. Tüpler 3000 rpm'de 10 dakika santrifüj edildikten sonra üstte toplanan serum 2 ml'lik ependorf tüplerine aktarılmıştır. Serumlar analiz yapılıncaya kadar $-80^{\circ} \mathrm{C}$ 'deki derin dondurucuda muhafaza edilmiştir. Kan serumu örneklerinde, otoanalizör cihazı (Olympus AU400 Chemistry Analyzer-OLYAU400) ve ticari kitler (Beckman Coulter OSR) kullanılarak fotometrik yöntemle Alkalen Fosfataz (ALP, IU/I), Alanin Aminotransferaz (ALT, IU/I), Aspartat Transaminaz (AST, IU/I), Laktat Dehidrogenaz (LDH, IU/I), Trigliserid (TG, $\mathrm{mg} / \mathrm{dl})$, Glikoz (mg/dl), Toplam Kolesterol $(\mathrm{mg} / \mathrm{dl})$, HDL-Kolesterol (HDL-C, $\mathrm{mg} / \mathrm{dl})$ ve LDLKolesterol (LDL-C, mg/dl) değerleri ölçülmüştür.
Araştırmadan elde edilen verilerin istatistiksel analizi SAS 9.1.3 istatistik paket programı kullanılarak yapılmıştır (SAS, 2003). Önemli bulunan ortalamalar arasındaki farklılıkların belirlenmesinde Duncan testi kullanılmıştır.

\section{Bulgular ve Tartışma \\ Canlı ağırlık}

Deneme başlangıcında (9 haftalık yaşta) tesadüfi olarak oluşturulan deneme gruplarının canlı ağırlık değerleri 200.7-209.0 g arasında değişim göstermiştir. Yapılan istatistiksel analizlerde kontrol ve muamele gruplarına ait canlı ağırlıklar arasındaki farklılıklar önemsiz bulunmuştur (Çizelge 2).

Çizelge 2. Deneme gruplarına ait bıldırcınların canlı ağılık değişimleri.

Deneme gruplarına ait canlı ağırlıklar, g

\begin{tabular}{lcc}
\hline Gruplar & 9. hafta & 16. hafta \\
Kontrol & 207.2 & $242.3 \mathrm{~b}$ \\
$0.5 \mathrm{~g} / \mathrm{kg} \mathrm{PKY}$ & 209.0 & $247.4 \mathrm{~b}$ \\
$1 \mathrm{~g} / \mathrm{kg} \mathrm{PKY}$ & 207.9 & $259.4 \mathrm{a}$ \\
$0.5 \mathrm{~g} / \mathrm{kg} \mathrm{NÇY}$ & 200.7 & $248.9 \mathrm{ab}$ \\
$1 \mathrm{~g} / \mathrm{kg} \mathrm{NÇY}$ & 208.1 & $239.6 \mathrm{~b}$ \\
$\mathrm{P}$ & ÖNZ & $*$ \\
\hline
\end{tabular}

$a, b$ : Aynı sütunda farklı harfle gösterilen ortalamalar arasındaki farklılıklar önemlidir. ÖNZ: Önemsiz, $*: \mathrm{P}<0.05$.

Denemenin sonunda (16 haftalık yaşta), diyete ilave edilen PKY ve NÇY yağının, kontrol ve muamele gruplarına ait canlı ağırlıklarda istatistiksel olarak farklılıklara neden olduğu saptanmıştır. Canlı ağırlıklara ilişkin sonuçlara göre, diyetlere ilave edilen 1 $\mathrm{g} / \mathrm{kg}$ PKY ve $0.5 \mathrm{~g} / \mathrm{kg} N C ̧ Y^{\prime} n ı n$, bıldırcınların canlı ağırlıkları üzerine etkisi önemli $(P<0.05)$ bulunurken, diğer gruplardaki canlı ağırlıkların değişimleri önemsiz olmuştur. Abdel-Wahab ve Mosad (2018), diyetlerine farklı düzeylerde (\%0.5-1.5) nar kabuğu tozu ilave ettikleri bıldırcınların canlı ağırlıklarının önemli ölçüde arttığını bildirmişlerdir. Dalkılıç ve ark., (2015), bıldırcın diyetlerine yapılan 300 ppm PKY ilavesinin canlı ağırlık kazancını olumlu yönde etkilediğini açıklamışlardır. Karabayır ve ark., (2018) ise, bıldırcın diyetlerine 200-600 ppm düzeylerinde PKY ilave ettiklerinde büyüme performansının etkilenmediğini bildirmişlerdir. Saki ve ark., (2014), yumurtacı tavukların diyetlerine \%5-15 oranlarında nar çekirdeği küspesi ilavesinin canlı ağırık kazancını etkilemediğini bildirmişlerdir. Diğer bir çalışmada ise, Abbas ve ark., (2017) bıldırcın diyetlerinde mısır yerine \%2.5-7.5 oranlarında kullanılan nar posası tozunun canlı ağırlıklar üzerine etkili olmadığını belirlemişlerdir.

\section{Yumurta verimi ve yumurta ağırlığı}

Kontrol ve muamele gruplarına ait bıldırcınların yumurta verimi ve yumurta ağılıklarına ilişkin değerler Çizelge 3'te verilmiştir.

Illk haftada, yumurta verimi bakımından gruplar arasındaki farklılıklar önemsizken, daha sonraki haftalarda önemli $(P<0.05, P<0.01)$ olmuştur. 11. 13., 15. ve 16. haftalarda $1 \mathrm{~g} / \mathrm{kg}$ PKY katkılı grup diğer gruplara oranla önemli derecede daha yüksek yumurta verimine sahip olmuştur. 
Kontrol grubu 11. haftada en düşük yumurta verimine sahip olurken, diğer haftalarda diğer muamele gruplarına benzer düzeyde yumurta vermiştir. Diyete PKY katkısının yumurta verimini olumlu yönde etkilediği söylenilebilir. Yumurta ağırlı̆̆ bakımından ise, denemenin ilk haftası dışındaki tüm haftalarda önemli $(P<0.05)$ farklılıklar gözlenmiştir. 11 . haftadan 16. haftaya kadar olan dönemde elde edilen yumurta ağırlıkları $1 \mathrm{~g} / \mathrm{kg}$ PKY katkılı grupta diğer gruplardan daha yüksek bulunmuştur. Sonuçlar, yumurta ağırlığının diyete ilave edilen $1 \mathrm{~g} / \mathrm{kg}$ düzeyindeki PKY katkısından etkilendiğini göstermiştir. Karabayır ve ark., (2018), bıldırcın diyetlerine 200-600 ppm düzeylerinde PKY ilave ettiklerinde, yumurta ağırlığının önemli düzeyde etkilendiğini bildirmişlerdir. Yapılan farklı bir çalışmada, bıldırcın diyetlerinde, mısır yerine \%2.5-7.5 oranlarında nar posası tozu kullanıldığında, yumurta verimi ve yumurta ağırlığında artışa neden olduğu bildirilmiştir (Abbas ve ark., 2017). Diğer bir çalışmada ise, Saki ve ark., (2014), yumurtacı tavukların diyetlerine \%5-15 oranlarında nar çekirdeği küspesi ilavesinin yumurta ağırlığı üzerine etkili olmadığını bildirmişlerdir. Aynı çalışmada, \%5 oranında kullanılan nar çekirdeği küspesinin yumurta verimini arttırdığını, ancak \%15 oranında kullanıldığında ise düşürdüğü belirlenmiştir. Erişir ve ark. (2015), bıldırcın diyetlerine 200 ppm düzeyinde PKY ilave etmenin yumurta verimi ve yumurta ağırlığı üzerine etkili olmadığını açıklamışlardır. Sevim ve ark., (2020), bıldırcın diyetlerine farklı düzeylerde ilave edilen $\mathrm{PKY}^{\prime}$ nın yumurta verimi ve yumurta ağırlığını etkilemediğini bildirmişlerdir.

Çizelge 3. Deneme gruplarına ait bıldırcınlarının yumurta verimi ve yumurta ağırlığına ilişkin değerler.

\begin{tabular}{|c|c|c|c|c|c|}
\hline \multirow[b]{2}{*}{ Gruplar } & \multicolumn{5}{|c|}{ Yumurta verimi, \% } \\
\hline & 9. hafta & 11. hafta & 13. hafta & 15. hafta & 16. hafta \\
\hline Kontrol & 78.0 & $91.6 d$ & $93.6 c$ & $93.0 c$ & $93.6 b$ \\
\hline $0.5 \mathrm{~g} / \mathrm{kg}$ PKY & 79.9 & $95.0 \mathrm{~b}$ & $95.0 \mathrm{~b}$ & $95.3 b$ & $94.0 \mathrm{~b}$ \\
\hline $1 \mathrm{~g} / \mathrm{kg} \mathrm{PKY}$ & 80.3 & $98.3 a$ & $98.3 a$ & $98.0 a$ & $96.0 a$ \\
\hline $0.5 \mathrm{~g} / \mathrm{kg} \mathrm{NÇY}$ & 79.6 & $93.0 c$ & $94.3 b c$ & $94.3 c$ & $93.6 b$ \\
\hline $1 \mathrm{~g} / \mathrm{kg} \mathrm{NÇY}$ & 79.6 & $93.0 \mathrm{c}$ & $93.6 c$ & $94.0 c$ & $92.6 b$ \\
\hline$P$ & ÖNZ & $* *$ & $* *$ & $*$ & $*$ \\
\hline
\end{tabular}

Yumurta ağırlığı, g

\begin{tabular}{lccccc}
\hline Kontrol & $11.65 a b$ & $11.81 c$ & $12.40 b$ & $12.36 b$ & $12.33 b$ \\
$0.5 \mathrm{~g} / \mathrm{kg} \mathrm{PKY}$ & $11.87 a b$ & $12.75 b$ & $12.69 b$ & $12.65 b$ & $12.57 b$ \\
$1 \mathrm{~g} / \mathrm{kg} \mathrm{PKY}$ & $12.63 a$ & $13.61 a$ & $13.76 a$ & $13.62 a$ & $13.59 a$ \\
$0.5 \mathrm{~g} / \mathrm{kg} \mathrm{NÇY}$ & $11.42 b$ & $12.18 b c$ & $12.29 b$ & $12.35 b$ & $12.39 b$ \\
$1 \mathrm{~g} / \mathrm{kg} \mathrm{NÇY}$ & $11.97 a b$ & $11.93 b c$ & $12.36 b$ & $12.11 b c$ & $12.58 b$ \\
$\mathrm{P}$ & ÖNZ & $*$ & $*$ & $*$ & $*$ \\
\hline
\end{tabular}

$a, b, c, d$ : Aynı sütunda farklı harfle gösterilen ortalamalar arasındaki farklııklar önemlidir. ÖNZ: Önemsiz, *: P<0.05, $* *: \mathrm{P}<0.01$. 
Yem tüketimi ve yemden yararlanma oranı

Deneme gruplarına ait bıldırcınların diyetlerine ilave edilen katkıların yem tüketimi ve yemden yararlanma oranları üzerine etkileri incelenmiş ve elde edilen sonuçlar haftalık olarak Çizelge 4'te verilmiştir.

Çizelge 4. Deneme gruplarına ait bıldırcınların yem tüketimleri ve yemden yararlanma oranları.

\begin{tabular}{|c|c|c|c|c|c|}
\hline \multirow{2}{*}{ Gruplar } & \multicolumn{5}{|c|}{ Günlük yem tüketimi, g } \\
\hline & 9. hafta & 11. hafta & 13. hafta & 15. hafta & 16. hafta \\
\hline Kontrol & $32.82 b c$ & $35.94 c d$ & $40.46 a$ & $39.91 a b$ & 38.25 \\
\hline $0.5 \mathrm{~g} / \mathrm{kg}$ PKY & $32.91 b c$ & $35.54 c d$ & $33.20 e$ & $38.12 a b c$ & 37.98 \\
\hline $1 \mathrm{~g} / \mathrm{kg}$ PKY & $37.61 a$ & $36.96 b c$ & $38.11 b$ & $38.81 a b c$ & 37.85 \\
\hline $0.5 \mathrm{~g} / \mathrm{kg} \mathrm{NÇY}$ & $37.01 a$ & $37.31 b$ & $35.95 b c d$ & $37.72 b c$ & 37.95 \\
\hline $1 \mathrm{~g} / \mathrm{kg} \mathrm{NÇY}$ & $35.44 a b$ & $40.00 a$ & $37.55 b c$ & $40.17 a$ & 39.36 \\
\hline \multirow[t]{2}{*}{$P$} & $* *$ & $* *$ & $* *$ & $* *$ & ÖNZ \\
\hline & \multicolumn{5}{|c|}{ Haftalık yem tüketimi, g } \\
\hline Kontrol & $229.75 b c$ & $251.55 \mathrm{bcd}$ & $283.19 a$ & $279.38 a b$ & 267.74 \\
\hline $0.5 \mathrm{~g} / \mathrm{kg}$ PKY & $230.36 b c$ & $248.75 c d$ & $232.41 e$ & $266.83 a b c$ & 265.83 \\
\hline $1 \mathrm{~g} / \mathrm{kg} P K Y$ & $263.25 a$ & $258.75 b c$ & $266.78 b$ & $271.69 a b c$ & 264.97 \\
\hline $0.5 \mathrm{~g} / \mathrm{kg} \mathrm{NÇY}$ & $259.05 a$ & $261.16 b$ & $251.66 b c d$ & $264.05 b c$ & 265.66 \\
\hline $1 \mathrm{~g} / \mathrm{kg} \mathrm{NÇY}$ & $248.11 a b$ & $280.26 a$ & $262.83 b c$ & $281.16 a$ & 275.53 \\
\hline \multirow[t]{2}{*}{$P$} & $* *$ & $* *$ & $* *$ & $* *$ & ÖNZ \\
\hline & \multicolumn{5}{|c|}{ Kümülatif yem tüketimi, g } \\
\hline Kontrol & $229.75 b c$ & $704.64 c d$ & $1259.02 a b$ & $1811.19 a$ & $2078.93 a b$ \\
\hline $0.5 \mathrm{~g} / \mathrm{kg}$ PKY & $230.36 b c$ & $692.25 d$ & $1187.77 c$ & $1718.30 b$ & $1984.14 \mathrm{C}$ \\
\hline $1 \mathrm{~g} / \mathrm{kg}$ PKY & $263.25 a$ & $758.97 a$ & $1299.44 a$ & $1833.61 a$ & $2098.58 a b$ \\
\hline $0.5 \mathrm{~g} / \mathrm{kg} N C ̧ Y$ & $259.05 a$ & $761.55 a$ & $1293.19 a$ & $1818.52 a$ & $2084.19 a b$ \\
\hline $1 \mathrm{~g} / \mathrm{kg} \mathrm{NÇY}$ & $248.11 a b$ & $753.05 a$ & $1297.00 a$ & $1838.31 a$ & $2113.88 a$ \\
\hline \multirow[t]{2}{*}{$P$} & $* *$ & $* *$ & $*$ & $* *$ & $* *$ \\
\hline & \multicolumn{5}{|c|}{ Yemden yararlanma oranı, g/g } \\
\hline Kontrol & $3.55 b c$ & $3.29 d c$ & $3.06 c$ & $3.10 d c$ & $3.22 b$ \\
\hline $0.5 \mathrm{~g} / \mathrm{kg}$ PKY & $3.61 a b$ & $3.59 a b$ & $3.82 a$ & $3.32 a b c$ & $3.31 b$ \\
\hline $1 \mathrm{~g} / \mathrm{kg}$ PKY & $3.35 b c$ & $3.69 a$ & $3.61 a b$ & $3.51 a$ & $3.59 a$ \\
\hline $0.5 \mathrm{~g} / \mathrm{kg} \mathrm{NÇY}$ & $3.08 c$ & $3.26 d$ & $3.41 b$ & $3.27 a b c$ & $3.26 b$ \\
\hline $1 \mathrm{~g} / \mathrm{kg} \mathrm{NÇY}$ & $3.38 b c$ & $2.98 e$ & $3.29 b c$ & $3.01 d$ & $3.20 b$ \\
\hline$P$ & $*$ & * & * & $* *$ & * \\
\hline
\end{tabular}


Yem katkılarının bıldırcınların günlük yem tüketimleri üzerine 16 . haftaya kadar etkili olduğu $(P<0.01)$ gözlemlenmiştir. 9. haftadaki yem tüketimlerine bakıldığında, $1 \mathrm{~g} / \mathrm{kg}$ PKY ve $0.5 \mathrm{~g} / \mathrm{kg}$ NÇY ilaveli grupların daha fazla yem tükettikleri görülmektedir. 11. haftada $1 \mathrm{~g} / \mathrm{kg}$ NÇY grubu daha yüksek yem tüketimine sahip olmuştur. Yem tüketimi bakımından, 13. haftada kontrol grubu öne çıkarken, 15. haftada $1 \mathrm{~g} / \mathrm{kg}$ NÇY ve kontrol grupları daha fazla yem tüketmişlerdir. 16. haftada ise, gruplar arasındaki farklılıklar önemli bulunmamıştır. Grupların haftalık yem tüketimlerine bakıldığında günlük yem tüketimine benzer şekilde, 16. hafta dışındaki tüm haftalarda önemli $\quad(P<0.01)$ farklılıklar gözlenmiştir. Kümülatif yem tüketimi bakımından, tüm haftalarda önemli farklılıklar görülmüş ve yem katkılarının deneme süresince etkili olduğu saptanmıştır (Çizelge 4). Denemenin 9., 11. ve 15 haftalarında, muamele grupları kontrol grubuna oranla daha fazla yem tüketirken, 13. haftada kontrol grubu en fazla yem tüketen grup olmuştır. 16. haftada ise, tüm gruplar arasındaki farklılıklar önemsiz bulunmuştur. Kümülatif yem tüketimi bakımından 9. ve 11 . haftalarda kontrol ve $0.5 \mathrm{~g} / \mathrm{kg}$ PKY grupları en az yem tüketen gruplar olurken, 13. ve 15 haftalarda $0.5 \mathrm{~g} / \mathrm{kg}$ PKY grubu kontrol ve diğer muamele gruplarına oranla önemli $(P<0.05$, $\mathrm{P}<0.01)$ derecede daha az yem tüketmişlerdir. Denemenin son haftasında ise, genelde tüm gruplar birbirlerine benzer düzeyde yem tüketirken, yine $0.5 \mathrm{~g} / \mathrm{kg}$ PKY katkılı grup tüm gruplardan daha az yem tüketmiştir. Diyetlerine farklı düzeylerde (\%0.5-1.5) nar kabuğu tozu ilave edilen bıldırcınların yem tüketiminin önemli miktarda azaldığı bildirilmiştir (AbdelWahab ve Mosad, 2018). Benzer şekilde, Erişir ve ark. (2015)'da bıldırcın diyetlerine 200 ppm düzeyinde PKY ilave ettiklerinde yem tüketiminin düştüğünü belirlemişlerdir. Yapılan diğer bir çalışmada ise, bıldırcın diyetlerine 300 ppm ilave edilen PKY ilavesinin yem tüketimini arttırdığı bildirilmiştir (Dalkılıç ve ark., (2015). Saki ve ark., (2014), yumurtacı tavukların diyetlerine \%5-15 oranlarında nar çekirdeği küspesi ilavesinin yem tüketimini etkilemediğini açıklamışlardır. Diğer bir çalışmada, Abbas ve ark., (2017) bıldırcın diyetlerinde mısır yerine \%7.5 oranında kullanılan nar posası tozunun yem tüketimini arttırdığını bildirmişlerdir. Sevim ve ark., (2020) ise, bıldırcın diyetlerine farklı düzeylerde ilave edilen $\mathrm{PKY}^{\prime}$ nın yem tüketimini önemli ölçüde etkilemediğini açıklamışlardır.

Deneme gruplarının yemden yararlanma oranları arasındaki farklılıklar tüm haftalar için önemli bulunmuş ve elde edilen sonuçlar Çizelge 4 'te verilmiştir. 9. haftada $0.5 \mathrm{~g} / \mathrm{kg} \mathrm{NÇY}$ katkılı grup yemden yararlanma bakımından en iyi durumda olurken, bunu $1 \mathrm{~g} / \mathrm{kg}$ PKY ve $1 \mathrm{~g} / \mathrm{kg}$ NÇY grupları izlemiştir. 11. haftada $1 \mathrm{~g} / \mathrm{kg} \mathrm{NÇY}$ katkılı grup, 13. haftada kontrol grubu, 15. haftada $1 \mathrm{~g} / \mathrm{kg} \mathrm{NÇY}$ ve kontrol grubu en iyi yemden yararlanan gruplar olmuştur. 16. haftada ise $1 \mathrm{~g} / \mathrm{kg}$ PKY grubu dışındaki gruplar benzer sonuçlar vermişler ve söz konusu gruptan daha iyi performans göstermişlerdir. Diyetlerine farklı düzeylerde (\%0.5-1.5) nar kabuğu tozu ilave edilen bıldırcınlarda, yemden yararlanmanın önemli düzeyde iyileştiği bildirilmiştir (Abdel-Wahab ve Mosad, 2018). Erişir ve ark. (2015), bıldırcın diyetlerine 200 ppm düzeyinde PKY ilave ettiklerinde, yemden yararlanma oranının etkilenmediğini açıklamışlardır. Diğer bir çalışmada ise, Dalkılıç ve ark., (2015) bıldırcın diyetlerine 300 ppm PKY ilave edildiğinde yemden yararlanma oranının olumlu yönde etkilediğini bildirmişlerdir. Saki ve ark., (2014), yumurtacı tavukların diyetlerine \%5-15 oranlarında nar çekirdeği küspesi ilavesinin, yemden yararlanma oranını etkilemediğini açıklamışlardır. Sevim ve ark., (2020), bıldırcın diyetlerine farklı düzeylerde ilave edilen $P K Y^{\prime}$ nın yemden yararlanma oranı üzerine etkili olmadığını bildirmişlerdir.

\section{Yumurta kalitesi}

Çalışmada, denemenin ilk haftası ( 9 . hafta) ve son haftasında (16. hafta) kontrol ve muamele gruplarından toplanan yumurtaların dış ve iç kalite ölçümleri yapılmış ve sonuçlar Çizelge 5'te verilmiştir. 
Çizelge 5. Deneme gruplarına ait yumurtaların bazı kalite özelliklerindeki değişimler.

Katkı düzeyleri

Özellikler Hafta Kontrol $0.5 \mathrm{~g} / \mathrm{kg}$ PKY $\quad 1 \mathrm{~g} / \mathrm{kg}$ PKY $\quad 0.5 \mathrm{~g} / \mathrm{kg} \mathrm{NÇY} \quad 1 \mathrm{~g} / \mathrm{kg}$ NÇY $\quad P$

\begin{tabular}{lcccccc}
\hline $\begin{array}{l}\text { Şekil } \\
\text { indeksi (\%) }\end{array}$ & 9. & $76.78 b$ & $76.85 b$ & $75.84 b$ & $76.09 b$ & $80.36 a$ \\
& 16. & $79.42 a$ & $76.45 b$ & $75.17 b$ & $77.00 b$ & $76.81 b$ \\
$\begin{array}{l}\text { Kabuk kal. } \\
\text { (mm) }\end{array}$ & 9. & $0.23 c$ & $0.24 a$ & $0.24 a$ & $0.23 a b$ & $0.24 a$ \\
& 16. & $0.23 c$ & $0.24 a$ & $0.24 a$ & $0.24 a b$ & $0.24 a$ \\
$\begin{array}{l}\text { Kabuk ağ. } \\
\text { (g) }\end{array}$ & 9. & $1.25 a$ & $1.19 d$ & $1.24 a b$ & $1.22 b c d$ & $1.21 b c d$ \\
& 16. & $1.15 a$ & $1.10 b$ & $1.13 a b$ & & \\
$\begin{array}{l}\text { Sarı ağırlığı } \\
\text { (g) }\end{array}$ & 9. & $4.19 b$ & $4.17 b$ & $4.38 a$ & $4.24 a b$ & $4.45 a$
\end{tabular}

(g)

indeksi

16. $4.18 c \quad 4.17$

$4.48 a \quad 4.15 c \quad 4.35 a b$

Sarı

9. $44.71 a-40.99 c d$

$43.84 a b$

38.88 de

$43.10 a b c$

(\%)

16. $44.34 a b$

$40.93 d$

$44.15 a b$

$40.41 d$

$43.33 a b c$

Ak indeksi

9. $9.82 a \quad 9.33 a b$

$9.11 a b$

$9.65 a$

$8.75 b$

(\%)

16. 9.62

9.42

9.55

9.44

9.03

ÖNZ

Haugh

9. 91.62

90.55

90.42

91.31

90.12

ÖNZ

birimi

16.

90.71

91.04

90.44

90.59

90.07 ÖNZ

9.
$\mathrm{L} \quad 39.45 b$
$37.20 c$
$36.54 c d$
$37.30 c$
$41.30 a$

Sarı rengi

$\begin{array}{ccccccc}\text { a } & 6.14 e & 7.61 a b & 7.75 a & 6.99 c d & 7.63 a b & * * \\ \text { b } 34.53 a b & 33.57 c & 34.87 a & 34.02 a b c & 33.60 b c & * * \\ \text { L } & 37.95 b & 35.68 c & 35.04 d c & 35.83 c & 39.46 a & *\end{array}$

16.

$\begin{array}{lllll}\text { a } \quad 6.99 e & 8.53 a b & 8.56 a & 7.82 c d & 8.49 a b \\ \text { b } 35.76 a b & 35.02 b c & 36.04 a & 35.26 a b c & 34.62 c\end{array}$

$a, b, c, d, e$ : Aynı sütunda farklı harfle gösterilen ortalamalar arasındaki farklılıklar önemlidir. ${ }^{*}: \mathrm{P}<0.05$, $* *$ : P<0.01, ÖNZ: Önemsiz. 
Diyete ilave edilen katkılar, yumurta kalitesi olarak 16. haftadaki ak indeksi, 9. ve 16. haftalardaki Haugh birimi değerleri dışındaki tüm özellikleri önemli düzeyde etkilemiştir $(P<0.05, P<0.01)$.

Çizelge 6. Deneme gruplarına ait bıldırcınların kan parametrelerine ilişkin sonuçlar. Katkı düzeyleri

\begin{tabular}{|c|c|c|c|c|c|c|}
\hline Kan parametreleri & Kontrol & $0.5 \mathrm{~g} / \mathrm{kg} \mathrm{PKY}$ & $1 \mathrm{~g} / \mathrm{kg}$ PKY & $0.5 \mathrm{~g} / \mathrm{kg} \mathrm{NÇY}$ & $1 \mathrm{~g} / \mathrm{kg} \mathrm{NÇY}$ & $P$ \\
\hline T. Kolesterol (mg/dl) & $310.0 a b$ & $290.2 a b$ & $327.5 a$ & $288.8 b$ & $306.7 a b$ & $*$ \\
\hline Trigliserit (mg/dl) & $1383.0 a b$ & $1308.2 b$ & $1463.7 a b$ & $1496.0 a$ & $1435.3 a b$ & $*$ \\
\hline Glikoz (mg/dl) & 293.0 & 297.3 & 282.2 & 285.8 & 278.5 & ÖNZ \\
\hline $\mathrm{HDL}(\mathrm{mg} / \mathrm{dl})$ & $87.50 b$ & $84.33 b$ & $104.50 a$ & $87.00 b$ & $90.50 b$ & $*$ \\
\hline $\mathrm{LDL}(\mathrm{mg} / \mathrm{dl})$ & 77.02 & 55.80 & 57.56 & 97.46 & 95.00 & ÖNZ \\
\hline ALP (IU/I) & $570.5 b$ & $517.2 b$ & $723.5 a$ & $567.8 b$ & $562.3 b$ & $*$ \\
\hline ALT (IU/I) & 1.50 & 1.83 & 1.66 & 1.16 & 1.33 & ÖNZ \\
\hline AST (IU/I) & $201.5 a b$ & $208.0 a$ & $204.3 a$ & $207.2 a$ & $198.8 b$ & $*$ \\
\hline LDH (IU/I) & $601.8 a$ & $473.2 a b$ & $495.7 a b$ & $451.3 b$ & $480.7 a b$ & $*$ \\
\hline $\mathrm{MDA}(\mathrm{nmol} / \mathrm{ml})$ & 1.186 & 1.176 & 1.188 & 1.175 & 1.175 & ÖNZ \\
\hline
\end{tabular}

a,b: Aynı satırda farklı harfle gösterilen ortalamalar arasındaki farklılıklar önemlidir. ÖNZ: Önemsiz,

$*: \mathrm{P}<0.05$.

Şekil indeksi bakımından, 9. haftada 1 $\mathrm{g} / \mathrm{kg}$ NÇY katkılı grup diğerlerinde önemli düzeyde daha yüksek değer göstermiştir. 16. haftada ise, kontrol grubu en yüksek değere sahip olan grup olmuştur. Yem katkıları her iki haftada da kabuk kalınlığı üzerine etkili olmuş ve kontrol grubu en ince kabuk kalınlığına sahip olan grup olmuştur. Kabuk ağırlığı bakımından, 9. haftada kontrol ve $1 \mathrm{~g} / \mathrm{kg}$ PKY katkılı gruplar en yüksek değere sahip olurken, 16. haftada 0.5 $\mathrm{g} / \mathrm{kg}$ PKY katkılı grup diğerlerine oranla daha düşük kabuk ağırlığına sahip olmuştur. Diyete ilave edilen katkılar, sarı ağırlığını önemli derecede etkilemiş olup, 9. haftada en düşük değerler $0.5 \mathrm{~g} / \mathrm{kg}$ PKY ve kontrol gruplarında gözlenmiştir. 16. haftadaki sarı ağırlığı değerleri en yüksek $1 \mathrm{~g} / \mathrm{kg}$ PKY ve $1 \mathrm{~g} / \mathrm{kg}$ NÇY katkılı gruplardan elde edilmiştir. Grupların sarı indeksi değerleri, 9. ve 16. haftalarda, kontrol, 1 $\mathrm{g} / \mathrm{kg}$ PKY ve $1 \mathrm{~g} / \mathrm{kg}$ NÇY gruplarında diğer gruplara oranla daha yüksek bulunmuştur. Ak indeksi bakımından, $1 \mathrm{~g} / \mathrm{kg}$ NÇY katkılı grup diğer tüm gruplardan daha düşük sonuç verirken, 16. haftada gruplar arasındaki farklılıklar önemsiz bulunmuştur. Haugh birimine ilişkin değerler, tüm gruplarda her iki hafta için de benzer bulunmuştur. Deneme gruplarına ait yumurtaların sarı rengi üzerine 
yem katkılarının etkisi önemli olmuştur. L değeri bakımından en yüksek değer 9. ve 16 . haftalarda $1 \mathrm{~g} / \mathrm{kg}$ NÇY grubundan elde edilmiştir. a değeri bakımından, 9. ve 16 . haftalarda kontrol grubu en düşük değere sahip olmuş, diğer gruplar benzer birbirlerine sonuç vermişlerdir. b değeri bakımından ise, 9 . haftada, $0.5 \mathrm{~g} / \mathrm{kg}$ PKY katkılı grup en düşük değere sahip olmuş ve $1 \mathrm{~g} / \mathrm{kg}$ NÇY grubu dışındakilerden istatistiksel olarak önemli farklılıklar göstermiştir. 16. haftada, $1 \mathrm{~g} / \mathrm{kg}$ NÇY grubuna ait $b$ değeri diğer gruplardan daha düşük bulunmuştur. Karabayır ve ark., (2018), bıldırcın diyetlerine PKY ilavesinin yumurta sarısının b değeri ve yumurta akının a değerini önemli düzeyde etkilediğini bildirmişlerdir. Erişir ve ark. (2015), bıldırcın diyetlerine 200 ppm düzeyinde PKY ilave ettiklerinde, kabuk ağırlığı, sarı rengi ve haugh biriminin arttığını, şekil indeksinin ise etkilenmediğini açıklamışlardır. Diğer bir çalışmada, Saki ve ark., (2014), diyete \%5-15 oranlarında nar çekirdeği küspesi ilavesinin, yumurtacı tavuklarda sarı indeksi, ak indeksi, ve kabuk ağırlığı üzerine etkili olmadığını bildirmişlerdir. Abbas ve ark., (2017), bıldırcın diyetlerinde mısır yerine \%2.57.5 oranlarında kullanılan nar posası tozunun yemden yararlanma oranında iyileşmeye neden olduğunu açıklamışlardır. Sevim ve ark., (2020) ise, bıldırcınların diyetlerine ilave edilen PKY'nın kabuk kalınlığında önemli derecede azalmaya neden olduğunu bildirmişlerdir.

\section{Kan parametreleri}

Deneme gruplarına ait bıldırcınlardan alınan kan örneklerinin analizi sonucunda bazı kan parametrelerinin sonuçlarına ilişkin değerler Çizelge 6'da verilmiştir.

Elde edilen sonuçlar, diyete yapılan yağ katkılarının bıldırcınlarda toplam kolesterol, trigliserit, HDL, ALP (Alkalen fosfataz), AST (Alanin aminotransferaz) ve LDH (Laktat dehidrogenaz) düzeylerini istatistiksel anlamda önemli $\quad(P<0.05) \quad$ düzeyde etkilediğini göstermektedir. Kan kolesterol düzeyi bakımından, $1 \mathrm{~g} / \mathrm{kg}$ PKY ile $0.5 \mathrm{~g} / \mathrm{kg}$ NÇY katkılı gruplar dışında genelde benzer sonuçlar bulunmuştur. Trigliserit düzeyi, en yüksek 0.5 $\mathrm{g} / \mathrm{kg}$ NÇY grubunda ölçülmüş, diğer gruplar benzer sonuç vermişlerdir. HDL ve ALP düzeyleri, $1 \mathrm{~g} / \mathrm{kg}$ PKY katkılı grupta diğer gruplara oranla daha yüksek bulunmuştur. AST düzeyi bakımından, $1 \mathrm{~g} / \mathrm{kg}$ NÇY grubun en düşük değere sahip olduğu, diğer grupların ise benzer sonuçlar verdiği görülmüştür. Deneme gruplarına ait LDH düzeyleri önemli farklılıklar göstermiş ve $0.5 \mathrm{~g} / \mathrm{kg}$ NÇY grubu diğer gruplardan daha düşük değere sahip olmuştur. Yapılan analiz sonuçlarına göre, grupların kan glikoz, LDL, ALT ve MDA düzeyleri bakımından önemli farklılıklar göstermedikleri belirlenmiştir. Abdel-Wahab ve Mosad (2018), diyetlerine nar kabuğu tozu ilave edilen bıldırcınlarda, toplam kolesterol, LDL ve HDL düzeylerinin önemli ölçüde düştüğünü, trigliserit ve VLDL düzeylerinin ise etkilenmediğini bildirmişlerdir. Miguel ve ark., (2010), nar ürünlerinin antimikrobiyal ve bağışıklık sistemi ile ilgili aktivitelere ve karaciğer fonksiyonu, lipid ve glikoz metabolizması üzerine koruyucu etkilerinin olduğunu açıklamışlardır. Karabayır ve ark., (2018), bıldırcın diyetlerine PKY ilavesinin glikoz, ALP, AST, ALT ve LDH değerlerini etkilediğini, albumin, total protein, kolesterol ve trigliserit değerlerini ise etkilemediğini belirlemişlerdir. Diğer bir çalışmada, Saki ve ark., (2014), yumurtacı tavukların diyetlerine \%5-15 oranlarında nar çekirdeği küspesi ilavesinin kan trigliserit, HDL ve toplam antioksidan üzerine etkili olmadığını bildirmişlerdir. Diyete \%5 oranında nar çekirdeği küspesi ilavesinin ise, kan malondialdehit ve kolesterol düzeylerini arttırdığını belirlemişlerdir. Abbas ve ark., (2017), bıldırcın diyetlerinde mısır yerine \%2.57.5 oranlarında ikame edilen nar posası tozunun, kan kolesterolü, trigliserit, glikoz ve ALT oranlarını düşürdüğünü, toplam protein oranını ise etkilemediğini bildirmişlerdir. Sevim ve ark., (2020), bıldırcın diyetlerine (50-400 $\mathrm{mg} / \mathrm{kg}$ ) ilave edilen PKY'nın, kandaki total protein, ALT, AST ve glikoz konsantrasyonlarını etkilemediğini, kolesterol düzeyini ise önemli derecede düşürdüğünü $\left(400 \quad \mathrm{mg} / \mathrm{kg}^{\prime} \mathrm{da}\right)$ açıklamışlardır.

\section{Yumurta sarısındaki yağ, kolesterol ve MDA değerleri}

Kontrol ve muamele gruplarına ait yumurtaların sarılarında ölçülen yağ, kolesterol ve MDA (Malondialdehit) düzeylerine ilişkin değerler Çizelge 7'de verilmiştir. 
Çizelge 7. Deneme gruplarına ait bıldırcınların yumurta sarılarındaki yağ oranı, kolesterol düzeyi ve MDA içeriği.

\begin{tabular}{|c|c|c|c|}
\hline Gruplar & $\begin{array}{l}\text { Yağ oranı } \\
(\%)\end{array}$ & $\begin{array}{l}\text { Kolesterol düzeyi } \\
\text { (mg/yumurta sarısı) }\end{array}$ & $\begin{array}{l}\text { MDA içeriği } \\
\text { (nmol/mg) }\end{array}$ \\
\hline & 31.32 & & \\
\hline \multirow[t]{2}{*}{ Kontrol } & & $72.01 a$ & $0.43 a$ \\
\hline & 30.55 & & \\
\hline \multirow[t]{2}{*}{$0.5 \mathrm{~g} / \mathrm{kg}$ PKY } & & $58.19 d$ & $0.33 \mathrm{~cd}$ \\
\hline & 31.42 & & \\
\hline \multirow[t]{2}{*}{$1 \mathrm{~g} / \mathrm{kg}$ PKY } & & $54.85 c$ & $0.37 b c$ \\
\hline & 31.31 & & \\
\hline \multirow[t]{2}{*}{$0.5 \mathrm{~g} / \mathrm{kg} \mathrm{NÇY}$} & & $69.82 a b$ & $0.33 c d$ \\
\hline & 31.12 & & \\
\hline \multirow[t]{2}{*}{$1 \mathrm{~g} / \mathrm{kg} \mathrm{NÇY}$} & & $67.61 b$ & $0.32 d$ \\
\hline & ÖNZ & & \\
\hline$P$ & & $*$ & $*$ \\
\hline
\end{tabular}

a,b,c: Aynı sütunda farklı harfle gösterilen ortalamalar arasındaki farklılıklar önemlidir. ÖNZ: Önemsiz,

$*$ : $\mathrm{P}<0.05$.

Çizelge 7’ye bakıldığında, yem katkılarının muamele gruplarına ait yumurta sarılarının yağ düzeyini önemli düzeyde etkilemediği görülmektedir. Yumurta sarısı yağ düzeyi bakımından, kontrol grubu ile diğer tüm gruplara ait ortalamalar arasındaki farklılıklar önemsiz bulunmuştur. Kolesterol düzeyi bakımından ise, gruplar arasında önemli $(P<0.05)$ farklılıklar gözlenmiştir. Yumurta sarısı kolesterol düzeyi bakımından en yüksek değer kontrol ve $0.5 \mathrm{~g} / \mathrm{kg} \mathrm{NÇY}$ katkılı gruplardan elde edilmiştir. Diğer muamele grupları, bu iki gruptan daha düşük kolesterol değerine sahip olmuşlardır. En düşük kolesterol düzeyi $1 \mathrm{~g} / \mathrm{kg}$ PKY katkılı grupta saptanmıştır. Oksidatif stres hasarını gösteren ve lipid peroksidasyonun son ürünü olan malondialdehit (MDA), deneme gruplarına ait yumurta sarılarında önemli farklılıklar göstermiş ve en yüksek değer kontrol grubundan elde edilmiştir. Diyete uygulanan yem katkılarının MDA değerlerini önemli ölçüde düşürdüğü gözlenmiştir. Bu durum, PKY ve $N C ̧ Y^{\prime}$ ında bulunan ve antioksidan özellikteki bileşikler olan terpenlerin, peroksidasyonun ve dokulardaki oksidatif stresin önüne geçmesinden kaynaklandığı söylenilebilir.

\section{Yumurta sarısı yağ asidi kompozisyonu}

Deneme gruplarına ait bıldırcınlardan elde edilen yumurtaların sarılarının yağ asidi profiline ilişkin analiz sonuçları Çizelge 8'de verilmiştir.

Çizelge 8 incelendiğinde, deneme gruplarına ait yağ asidi oranlarının genelde önemli $\quad(P<0.05) \quad$ farklılıklar gösterdiği görülmektedir. Diyetlere farklı düzeylerde ilave edilen $\mathrm{PKY}$ ve NÇY'nın muamele gruplarının yumurta sarısı yağ asidi kompozisyonunda farklılaşmaya neden olduğu saptanmıştır. Yem katkılarından etkilenmeyen yağ asitleri, Linoleik asit, Araşidonik asit, MUFA (Tekli doymamış yağ asitleri), PUFA (Çoklu doymamış yağ asitleri) ve UFA (Doymamış yağ asitleri) olmuştur. Diğer tüm yağ asitleri bakımından gruplar arasında önemli farklılıklar gözlenmiştir. Karabayır ve ark., (2018), bıldırcın diyetlerine 200-600 ppm düzeylerinde portakal kabuğu yağı ilave ettiklerinde, tekli doymamış yağ asitleri düzeyinin arttığını, toplam doymuş yağ asitleri oranının ise düştüğünü bildirmişlerdir. 
Çizelge 8. Deneme gruplarına ait yumurtaların sarılarına ait yağ asidi kompozisyonu.

\begin{tabular}{|c|c|c|c|c|c|c|}
\hline \multirow[t]{2}{*}{ Yağ Asitleri } & \multicolumn{5}{|c|}{ Yağ asitleri kompozisyonu, \% } & \multirow[b]{2}{*}{$P$} \\
\hline & Kontrol & $\begin{array}{c}0.5 \mathrm{~g} / \mathrm{kg} \\
\text { PKY }\end{array}$ & $\begin{array}{c}1 \mathrm{~g} / \mathrm{kg} \\
\mathrm{PKY}\end{array}$ & $\begin{array}{c}0.5 \mathrm{~g} / \mathrm{kg} \\
\mathrm{NÇY}\end{array}$ & $\begin{array}{c}1 \mathrm{~g} / \mathrm{kg} \\
\mathrm{NÇY}\end{array}$ & \\
\hline Laurik Asit (C12:0) & $0.02 a$ & $0.01 b$ & $<0.01 c$ & $0.01 b$ & $<0.01 c$ & $*$ \\
\hline Tridekanoik Asit (C13:0) & $0.02 a$ & $<0.01 c$ & $<0.01 c$ & $0.02 b$ & $<0.01 c$ & $*$ \\
\hline Miristik Asit (C14:0) & $0.56 a$ & $0.34 c$ & $0.47 a b$ & $0.50 a$ & $0.45 a b$ & $*$ \\
\hline Pentadekanoik Asit (C15:0) & $0.14 a$ & $0.05 b c$ & $0.06 b$ & $0.06 b c$ & $0.06 b c$ & $*$ \\
\hline Palmitik Asit (C16:0) & $24.59 a$ & $11.28 b c$ & $16.00 b$ & $17.2 b$ & $13.6 b$ & $*$ \\
\hline Heptadekanoik Asit (C17:0) & $0.21 c$ & $0.25 a$ & $0.25 a$ & $0.25 a$ & $0.22 b$ & $*$ \\
\hline Stearik Asit (C18:0) & $7.21 a$ & $3.00 c$ & $3.00 c$ & $5.51 b$ & $5.00 b$ & $*$ \\
\hline Araşidik Asit (C20:0) & $0.60 b$ & $0.91 a$ & $<0.01 c$ & $<0.01 \mathrm{c}$ & $<0.01 c$ & $*$ \\
\hline Miristoleik Asit (C14:1) & $0.14 b$ & $0.69 a$ & $0.06 c$ & $0.07 c$ & $0.06 c$ & $*$ \\
\hline Palmiteloik Asit (C16:1) & $4.07 d$ & $5.54 b$ & $5.96 a$ & $4.05 d$ & $4.94 c$ & $*$ \\
\hline cis 10 -heptadekenoik Asit (C17:1) & $0.12 a$ & $1.18 a$ & $0.06 b$ & $0.07 b$ & $0.06 b$ & $*$ \\
\hline Oleik Asit (C18:1) & $41.10 b$ & $56.03 a$ & $56.83 a$ & $55.34 a$ & $56.15 a$ & $*$ \\
\hline Gadoleik Asit (C20:1) & $0.22 a$ & $<0.01 b$ & $<0.01 b$ & $<0.01 b$ & $<0.01 b$ & $*$ \\
\hline Linoleik Asit (C18:2) & 18.11 & 17.40 & 15.00 & 13.87 & 15.92 & ÖNZ \\
\hline Gama Linolenik Asit (C18:3) & $0.48 c$ & $0.85 b$ & $0.72 b$ & $1.07 b$ & $1.66 a$ & $*$ \\
\hline Cis-11,14-Eikosadienoik Asit (C20:2) & $0.11 b$ & $0.40 a$ & $<0.01 c$ & $<0.01 c$ & $<0.01 c$ & $*$ \\
\hline Araşidonik Asit (C20:4) & 1.18 & 1.60 & 1.56 & 1.87 & 1.78 & ÖNZ \\
\hline EPA (Eicosa Pentenoik Asit, C20:5) & $0.06 a$ & $0.03 b$ & $<0.01 c$ & $<0.01 c$ & $<0.01 c$ & $*$ \\
\hline DHA (Dokosaheksaenoik Asit, C22:6) & $0.44 a$ & $0.41 a$ & $0.08 b$ & $0.11 b$ & $0.10 b$ & * \\
\hline SFA (Doymuş Yağ Asitleri, \%) & $33.35 a$ & $15.84 c$ & $19.73 c$ & $23.55 b$ & $19.33 c$ & $*$ \\
\hline MUFA (Tekli Doym. Yağ Asit., \%) & 45.65 & 63.47 & 62.91 & 59.53 & 61.21 & ÖNZ \\
\hline PUFA (Çoklu Doym. Yağ Asit., \%) & 21.00 & 20.69 & 17.36 & 16.92 & 19.46 & ÖNZ \\
\hline UFA (Doymamış Yağ Asitleri, \%) & 66.65 & 84.16 & 80.27 & 76.45 & 80.67 & ÖNZ \\
\hline PUFA/SFA (\%) & $0.63 c$ & $1.31 a$ & $0.88 a b$ & $0.72 b c$ & $1.01 a$ & $*$ \\
\hline
\end{tabular}

$a, b, c, d, e, f:$ Aynı satırda farklı harfle gösterilen ortalamalar arasındaki farklııılar önemlidir. P: Önem düzeyi, ÖNZ: Önemsiz,

*: P<0.05. Doymuş Yağ Asitleri: (Laurik Asit + Tridekanoik Asit + Miristik Asit + Pentadekanoik Asit + Palmitik Asit + Heptadekanoik Asit+ Stearik Asit + Araşidik Asit). Tekli Doymamış Yağ Asitleri: (Miristoleik Asit + Palmitoleik Asit + cis 10 -heptadekenoik Asit + Oleik Asit + Gadoleik asit). Çoklu Doymamış Yağ Asitleri: (Linoleik Asit + Gama Linolenik Asit + cis-11,14-Eikosadienoik Asit + Araşidonik Asit + EPA (Eicosa Pentenoik Asit) + Dokosaheksaenoik Asit). 
Yumurta sarısı vitamin düzeyi

Kontrol ve muamele gruplarına ait edilen analiz sonuçlarına ilişkin ortalamalar bıldırcınların yumurta sarılarının vitamin Çizelge 9'da verilmiştir. düzeyleri (Vit $A$, Vit $D$ ve Vit $E$ ) bakımından elde

Çizelge 9. Deneme gruplarına ait yumurtaların sarılarındaki Vit A, D ve E düzeyleri.

\begin{tabular}{|c|c|c|c|}
\hline Gruplar & Vit A ( $\mu \mathrm{g} / \mathrm{g})$ & Vit D ( $\mu \mathrm{g} / 100 \mathrm{~g})$ & Vit E ( $\mu \mathrm{g} / \mathrm{g})$ \\
\hline Kontrol & 7.21 & 1.14 & $58.57 a$ \\
\hline $0.5 \mathrm{~g} / \mathrm{kg}$ PKY & 6.46 & 1.10 & $54.16 a b$ \\
\hline $1 \mathrm{~g} / \mathrm{kg}$ PKY & 6.82 & 1.19 & $54.64 a b$ \\
\hline $0.5 \mathrm{~g} / \mathrm{kg} \mathrm{NÇY}$ & 7.23 & 1.09 & $54.16 a b$ \\
\hline $1 \mathrm{~g} / \mathrm{kg} \mathrm{NÇY}$ & 7.27 & 1.13 & $51.01 b$ \\
\hline$P$ & ÖNZ & ÖNZ & $*$ \\
\hline
\end{tabular}

$a, b$ : Aynı sütunda farklı harfle gösterilen ortalamalar arasındaki farklııklar önemlidir. ÖNZ: Önemsiz, *: P<0.05.

Muamele gruplarının diyetlerine ilave edilen yem katkıları, Vit E bakımından gruplar arasında önemli $(P<0.05)$ farklılıklara neden olurken, Vit $A$ ve $V i t ~ D$ bakımından elde edilen sonuçlar benzer olmuştur. Yumurta sarılarının Vit $\mathrm{E}$ düzeyleri ile ilgili sonuçlara bakıldığında, $1 \mathrm{~g} / \mathrm{kg}$ NÇY katkılı grubun dışındaki grupların benzer sonuçlar verdiği, söz konusu gruba ilişkin değerin $(51.01 \mu \mathrm{g} / \mathrm{g})$ ise kontrol grubuna oranla önemli ölçüde düşük olduğu saptanmıştır.

\section{Sonuç ve Öneriler}

$\mathrm{Bu} \quad$ çalışmada, yumurtlama dönemindeki bıldırcınların yemlerine farklı düzeylerde $\mathrm{PKY}$ ve NÇY katılarak diyetlerin etkinliklerinin arttırılması amaçlanmıştır. Söz konusu katkılarla zenginleştirilen diyetlerin, bıldırcınların gerek verim performansı ve gerekse yumurta kalitesi ve bazı kan parametreleri bakımından etkileri araştırılmıştır. Elde edilen sonuçlar, yem katkısı olarak kullanılan yağların, bıldırcınların bazı performans özellikleri ve yumurta kalitesi üzerine önemli ölçüde etkili olduğunu göstermiştir. Denemenin ilk haftasında, deneme gruplarına ait bıldırcınların canlı ağırlıkları arasındaki farklılıklar önemli olmazken, denemenin son haftasında istatistiksel anlamda önemli farklılıklar saptanmıştır. $1 \mathrm{~g} / \mathrm{kg}$ PKY katkılı muamele grubu, kontrol grubuna oranla daha yüksek canlı ağırlığa sahip olmuştur. Yem katkılarının canlı ağırlıklar üzerine kısmen ve olumlu bir etki yaptığı söylenilebilir. Deneme gruplarının, gerek yem tüketimleri ve gerekse yemden yararlanma oranları üzerine yem katkılarının önemli düzeyde etki yaptığı gözlenmiştir. Kontrol ve muamele gruplarına ait günlük yem tüketimi değerleri, 16. hafta dışındaki tüm haftalarda önemli farklılıklar göstermiştir. 9. ve 11 . haftalarda, kontrol grubunun günlük yem tüketiminde diğer gruplara oranla belirli bir düşme gözlenmiş, ancak bu azalma 13. ve 15 . haftalarda ortadan kalkmıştır. Grupların haftalık ve kümülatif yem tüketimlerine bakıldığında ise, günlük yem tüketimine benzer sonuçlar elde edildiği görülmektedir. Yemden yararlanma oranı bakımından, tüm haftalarda, gruplara ait ortalamalar arasındaki farklılıklar önemli bulunmuştur. 9. haftada, $0.5 \mathrm{~g} / \mathrm{kg} \mathrm{NÇY}, 11$. haftada $1 \mathrm{~g} / \mathrm{kg} \mathrm{NÇY,} \mathrm{13.} \mathrm{haftada} \mathrm{kontrol} \mathrm{ve} 1$ $\mathrm{g} / \mathrm{kg} \mathrm{NÇY}, 15$. haftada $1 \mathrm{~g} / \mathrm{kg} \mathrm{NÇY}$ ve kontrol, 16. haftada ise $1 \mathrm{~g} / \mathrm{kg}$ PKY katkılı gruplar en iyi yemden yararlanan gruplar olmuştur. Yem katkılarının yemden yararlanma üzerine genelde olumlu bir etki yaptığı söylenilebilir. Abdel-Wahab ve Mosad (2018), diyete \%1 
oranında nar kabuğu tozu ilavesinin, bıldırcınların gerek verim performansı ve gerekse fizyolojik parametreleri üzerine önemli olumlu etkilerinin olduğunu bildirmişlerdir. Kontrol ve muamele gruplarına ait bıldırcınların yumurta verimi ve yumurta ağırlığının ilave yağ katkılarından olumlu yönde etkilendiği saptanmıştır. Elde edilen sonuçlara göre, diyete $1 \mathrm{~g} / \mathrm{kg}$ düzeyinde PKY katkısı gerek yumurta verimi ve gerekse yumurta ağırlığını önemli düzeyde arttırmıştır. Diyete ilave edilen yă̆ katkılarının, deneme gruplarının yumurtalarının dış ve iç kalitesi üzerine etkileri birkaç özellik dışında önemli olmuştur. Yumurta şekil indeksine ait ortalamalar, 11. haftada $1 \mathrm{~g} / \mathrm{kg}$ NÇY, 16. haftada ise kontrol grubunda en yüksek bulunmuştur. Uygulamaların şekil indeksini azaltıcı yönde etki yaptığı söylenilebilir. Kabuk kalınlığı üzerine yem katkılarının etkisi önemli olmuş ve tüm muamele grupları kontrol grubuna oranla daha kalın yumurta kabuğuna sahip olmuşlardır. Kullanılan her iki yağın da, kabuk kalınlığını olumlu yönde etkilediği görülmüştür. Kabuk ağırlığı, 16. hafta sonuçlarına göre $0.5 \mathrm{~g} / \mathrm{kg}$ PKY katkılı grup hariç diğer gruplarda etkilenmemiştir. Nar çekirdeği yağının her iki düzey bakımından da kabuk ağırlığı üzerine olumsuz bir etkisinin olmadığı saptanmıştır. Grupların 16. haftadaki sarı ağırlıklarına bakıldığında, $1 \mathrm{~g} / \mathrm{kg}$ PKY ve $1 \mathrm{~g} / \mathrm{kg}$ NÇY katkılı gruplarda kontrol grubuna oranla önemli artışlar gözlenmiştir. Diyete $1 \mathrm{~g} / \mathrm{kg}$ düzeyinde ilave edilen her iki katkının da sarı ağırlığı üzerine olumlu etki yaptığı söylenilebilir. Deneme gruplarının sarı indeksi değerleri, her iki haftada da önemli farklılıklar göstermiş olup, 16. haftada elde edilen sonuçlara göre $0.5 \mathrm{~g} / \mathrm{kg}$ düzeyinde kullanılan PKY ve NÇY sarı indeksini düşürmüştür. Ak indeksi bakımından 16 . haftadaki değerlere göre, gruplara ait ortalamalar arasındaki farklılıkların önemli bulunmadığı ve kullanılan katkıların söz konusu özellik üzerine etkili olmadığı görülmüştür. Hesaplanan Haugh birimi değerleri, her iki hafta bakımından da önemli olmamış ve yağ katkılarının etkili olmadığı belirlenmiştir. Kontrol ve muamele gruplarının yumurta sarılarının renk ölçümlerine göre, $L$, $a$ ve $b$ değeri bakımından oldukça farklı sonuçlar elde edilmiştir. 16. hafta sonuçlarına göre, $L$ değeri en yüksek $1 \mathrm{~g} / \mathrm{kg}$ NÇY katkılı grupta, a değeri en düşük kontrol grubunda ve $b$ değeri en düşük 1 $\mathrm{g} / \mathrm{kg}$ NÇY grubunda ölçülmüştür. a değeri üzerine her iki katkının da etkili olduğu söylenilebilir. Gruplardan alınan kan örnekleri analiz edildiğinde, toplam kolesterol, trigliserit, $H D L, A L P, A S T$ ve $L D H$ değerlerinin diyete ilave edilen yağ katkılarından etkilendiği görülmüştür. HDL ve ALP değerleri bakımından, $1 \mathrm{~g} / \mathrm{kg}$ PKY katkılı grupta, kontrol ve diğer gruplara oranla önemli bir artış görülmüştür. Söz konusu grupta iyi kolesterol olarak bilinen HDL'nin yüksek bulunması olumsuz bir sonuç olarak değerlendirilmemelidir. Özellikle iskelet sistemi ve mide-bağırsak sisteminde yoğun olarak üretilen bir enzim olan ALP'nin yüksek bulunması ise, $1 \mathrm{~g} / \mathrm{kg}$ PKY düzeyinin olumsuz bir etkisi olarak düşünülebilir. AST, karaciğer tarafından üretilen ve vücutta pek çok organda bulunan bir enzim olup, $1 \mathrm{~g} / \mathrm{kg}$ NÇY katkılı grup dışındaki tüm gruplarda benzer düzeylerde bulunmuştur. $1 \mathrm{~g} / \mathrm{kg} \mathrm{NÇY}$ katkılı grupta düşük düzeyde bulunan bu enzim, NÇY'nın söz konusu düzeyde kullanıldığında olumlu etkisinin olabileceğine işaret etmektedir. LDH düzeyi bakımından elde edilen sonuçlar, sadece 0.5 $\mathrm{g} / \mathrm{kg}$ NÇY katkılı grupta farklılık göstermiş ve bu grup diğerlerine oranla daha düşük değere sahip olmuştur. Vücuttaki tüm hücrelerde bulunan ve şekerden enerji elde etmek için kullanılan bir tür enzim olan LDH'nin yüksek olmaması istenir. $0.5 \mathrm{~g} / \mathrm{kg}$ NÇY uygulamasında söz konusu enzimin önemli düzeyde düşüş göstermesi olumlu bir etki olarak değerlendirilebilir.

Deneme gruplarına ait yumurtaların sarılarında ölçülen yağ, kolesterol ve MDA düzeylerine ilişkin değerlere bakıldığında, yağ katkılarının yumurta sarısının yağ düzeyi üzerine etkili olmadığı, fakat kolesterol ve MDA değerleri üzerine etkili olduğu saptanmıştır. Yumurta sarısı kolesterol düzeyi bakımından en yüksek olan grup, kontrol grubu olmuştur. Her iki yağ katkısının da yumurta sarısı kolesterol düzeyini düşürdüğü belirlenmiştir. Yumurta sarısının MDA içeriği bakımından da elde edilen sonuçlar önemli farklılıklar göstermiş olup, en yüksek değer kontrol grubunda ölçülmüştür. Elde edilen sonuçlara göre, diyete ilave edilen katkıların yumurta sarısının MDA düzeyinde düşüşe neden olduğu söylenilebilir. Syed ve ark., (2007), yüksek antioksidan kapasitesi ile bilinen nar ürünlerinin, yüzyıllardır tıbbi amaçlarla kullanıldığını bildirmiştir.

Deneme gruplarına ait bıldırcınlardan elde edilen yumurta sarılarının yağ asitleri profiline ilişkin analiz sonuçları önemli farklılıklar göstermiştir. Yemde kullanılan katkılar, birçok yağ asidinin düzeylerinde değişikliğe neden 
olmuştur. Linoleik asit ve Araşidonik asit dışındaki ölçülen tüm yağ asitlerinde farklılıklar gözlenmiştir. Palmitik asit, Stearik asit, Gadoleik asit, Eicosa Pentenoik asit ve SFA bakımından kontrol grubuna oranla muamele gruplarında önemli düşüşler görülürken, Heptadekanoik asit, Oleik asit ve Gama Linolenik asit bakımından muamele gruplarında önemli artışlar gözlenmiştir.

Kontrol ve muamele gruplarına ait bıldırcınların yumurtalarındaki vit $A$, vit $D$ ve vit $E$ analizlerine ilişkin sonuçlara bakıldığında, gruplar arasında sadece vit $E$ bakımından önemli farklılıklar görülmüştür. Diyete yağ katkısı ilavesinin, yumurta sarısındaki vit $A$ ve vit $D$ düzeylerini önemli düzeyde etkilemediği söylenilebilir. Ancak, vit E düzeyi bakımından $1 \mathrm{~g} / \mathrm{kg} N C ̧ Y$ grubunda daha düşük değerler gözlenirken, kontrol ve diğer muamele gruplarında benzer sonuçlar elde edilmiştir. NÇY'nin, diyete $1 \mathrm{~g} / \mathrm{kg}$ düzeyinde ilave edilmesi durumunda karşılaşılan bu durum olumsuz bir etki olarak dikkate alınabilir.

Sonuç olarak, bıldırcın diyetlerinin PKY ve NÇY ile belirli oranlarda $(0.5$ ve $1 \mathrm{~g} / \mathrm{kg})$ zenginleştirilerek hayvanlara verilmesinin, verim performansı, yumurta kalitesi, kan parametreleri ve yumurta sarısı yağ asidi profili gibi önemli özellikler üzerine belirgin bir olumsuz etkisi görülmemiştir. Buna karşılık, kullanılan katkıların birçok parametre üzerine olumlu etkiler yaptığı saptanmıştır. Muamele gruplarında, yumurta verimi, yumurta ağırlığı, kabuk kalınlığı, sarı ağırlığı, sarı rengi, HDL, AST, LDH, MDA ve yumurta sarısı kolesterol düzeyi gibi özellikler bakımından dikkati çeken iyileşmeler gözlenmiştir. Oksidatif stres hasarını gösteren MDA'nın, tüm muamele gruplarının yumurta sarılarında önemli oranda düşüşler göstermesi önemli bir bulgu olarak değerlendirilebilir. Uygulamalar, palmitik asit, stearik asit ve miristik asit gibi doymuş yağ asitlerinin düzeylerinde önemli düşüşlere; oleik asit, gama linoleik asit, heptadekanoik asit gibi yararlı yağ asitlerinde ise artışlara neden olmuştur. Kontrol grubuna oranla, muamele gruplarının doymuş yağ asitleri düzeyinde önemli azalmalar, PUFA/SFA oranında ise önemli artışlar görülmesi, her iki yem katkısının da özellikle yumurtanın besleme değeri açısından yararlı etkilerini göstermesi bakımından önemlidir.
Çıkar Çatışması Beyanı: Makale yazarları aralarında herhangi bir çıkar çatışması olmadığını beyan ederler.

Araştırmacıların Katkı Oranı Beyan Özeti: Yazarlar makaleye eşit oranda katkı sağlamış olduklarını beyan ederler.

\&: Bu çalışma Şebnem inci'nin doktora tezinden üretilmiştir.

\section{Kaynaklar}

Abbas, R.J., Al-Salhie, K.C.K., Al-Hummod, S.K.M., 2017. The effect of using different levels of pomegranate (Punica granatum) peel powder on productive and physiological performance of Japanese quail (Coturnix coturnix Japonica). Livestock Research for Rural Development 29:(12). 2017.

Abdel-Wahab, A.A., Mosad, A.S., 2018. Effect of adding pomegranate peels to growing Japanese quail diet on performance, blood and immunity parameters. Egyptian J. Nutrition and Feeds. 21(3): 771-782.

Akhtar, S., Ismail, T., Fraternale, D., Sestili, P., 2015. Pomegranate peel and peel extract: Chemistry and food features. Food Chemistry 174: 417-425.

Anonim, 2014. Lipid lowering effect of Punica granatum L. peel in high lipid diet fed male rats. http://dx.doi.org/10.1155/2014/43265 0 (erişim tarihi: 23.06.2017).

Atılgan, D., 2012. Etlik piliç karma yemlerine doğal antimikrobiyal olarak üzüm çekirdeği, zeytin yaprağı ve nar kabuğu ekstraktları ilavesinin besi performansı, serum ve bağırsak parametreleri üzerine etkilerinin karşılaştırılması. Yüksek Lisans Tezi. GOP Üniv.,Fen Bilimleri Enstitüsü Zootekni Anabilim Dalı, s. 53.

Bayrakdar, A., Dalkılıç, B., Yaman, M., Şimşek, Ü.G., Çiftçi, M., 2017. Effect of dietary orange peel essential oil and thermotolerance on histomorphometry and serotoninimmunoreactive endocrine cell numbers in the small intestines of heat stressed Japanese quails. Kafkas Univ 
Vet Fak Derg., 23 (2): 177-184. DOI: 10.9775/kvfd.2016.16116.

Bölükbaşı, Ş.C., Ürüşan, H., Erhan, M.K., Kızıltunç, A., 2010. Effect of dietary supplementation with bergamot oil (Citrus bergamia) on performance and serum metabolic profile of hens, egg quality and yolk fatty acid composition during the late laying period. Archiv für Geflügelkünde 74(3): 172-177.

Dahle, L.K., Hill, E.G., Holman, R.T., 1962. The thiobarbituric acid reaction and the autoxitadion of polyunsaturated fatty acid methyl esters. Archive Biochemical Biophysics 98(2): 253-261.

Dalkılıç, B., Şimşek, Ü.G., Çiftçi, M., Baykalır, Y., 2015. Effect of dietary orange peel essential oil on physiological, biochemical and metabolic responses of Japanese quails as affected by early age thermal conditioning and fasting. Revue Méd. Vét., 166, 5-6, 154-162.

De Melo, I.L.P., De Carvalho, E.B.T., ManciniFilho, J., 2014. Pomegranate seed oil (Punica granatum L.): A source of punicic acid (Conjugated $\alpha$-Linolenic acid). J Hum Nutr Food Sci 2(1): 1024.

Dündar, Y., 2001. Fitokimyasallar ve sağlıklı yaşam. Kocatepe Tıp Dergisi 2: 131138.

El-Shaarawy, M.I., Nahapetian, A., 1983. Studies on pomegranate seed oil. Fette. Seife. Anstrichmittel 85 (3), 123126.

Erişir, Z., Şimşek, Ü.G., Çiftçi, M., Yıldız, N., Dalkılıç, B., 2015. Portakal kabuğu yağı ve cinsiyet oranının yumurtacı bıldırcınlarda (Coturnix coturnix Japonica) yumurta verimi ve yumurta özellikleri üzerine etkisi. F.Ü. Sağ. Bil. Vet. Derg. 29 (1): 23-30.

Fadavi, A., Barzegar, M., Azizi, M.H., 2006. Determination of fatty acids and total lipid content in oilseed of 25 pomegranates varieties grown in Iran. J. Food Comp. Anal. 19, 676-680.

Folch, J., Lees, M., Stanley, G.H.S., 1957. A simple method for the isolation and purification of total lipides from animal tissues. The Journal of Biological Chemistry 226: 497-509

Güven, E.Ç., Otkun, G.T., Boyacıoğlu, D., 2010. Flavonoidlerin biyoyararlılığını etkileyen faktörler. Gıda. 35 (5): 387394.
Hegazy, A.E., Ibrahim, M.I., 2012. Antioxidant activities of orange peel extracts. World Applied Sciences Journal. 18(5):684-688.

Kamaliroosta, L., Zolfaghari, M., Shafiee, S., Larijani, K., Zojaji, M., 2016. Chemical identifications of citrus peels essential oils. Journal of Food Biosciences and Technology 6(2): 69-76.

Karabayır, A., Öğütçü, M., Acar, Ü., Arifoğlu, N., 2018. Effects of orange peel oil on quail (Coturnix coturnix Japonica) growth-performance, egg quality and blood parameters. New Knowledge Journal of Science. 7(2), 127-137. ISSN 2367-4598 (Online).

Liu, Y., Li, Y., Liu, H.N., Suo, Y.L., Hu, L.L., Feng, X.A., Zhang, L., Jın, F., 2013. Effect of quercetin on performance anf egg quality during the late laying period of hens. British Poultry Science 54(4): 510-514.

Mansour, E, Ben Khaled, A., Lachiheb, B., Abid, M., Bachar, K., Ferchichi, A., 2013. Phenolic compounds, antioxidant and antibacterial activities of peel extract from Tunisian pomegranate. Journal Agricultural Science and Technology 15: 1393-1403.

Meerts, I.A.T.M., Verspeek-Rip, C.M., Buskens, C.A.F., Keizer, H.G., Bassaganya-Riera, J., Jouni, Z.E., van Huygevoort, A.H.B.M., van Otterdijk, F.M., van de Waart, E.J., 2009. Toxicological evaluation of pomegranate seed oil. Food and Chemical Toxicology. 47,1085-1092.

Miguel, M.G., Neves, M.A., Antunes, M.D., 2010. Pomegranate (Punica granatum L.): A medicinal plant with myriad biological properties - A short review. Journal of Medicinal Plants Research. 4: 2836-2847.

Özgül-Yücel, S., 2005. Determination of conjugated linolenic acid content of selected oil seeds grown in Turkey. JAOCS 82 (12), 893-897.

Padmaja, A., Prasad, N.B.L., 2011. Pomegranate (Punica granatum L.) peel extract as a source of natural antioxidant. Journal of Food Science and Engineering 1: 171-178.

Saki, A.A., Rabet, M., Zamani, P., Yousefi, A., 2014. The effects of different levels of pomegranate seed pulp with multi- 
enzyme on performance, egg quality and serum antioxidant in laying hens. Iranian Journal of Applied Animal Science. 4(4), 803-808.

Sarıca, Ş., 2011. Nar suyu yan ürünlerinin hayvan beslemede kullanım olanakları. Gaziosmanpaşa Üniversitesi Ziraat Fakültesi Dergisi 28(2): 97-101

SAS., 2003. SAS 9.1.3 User Manual, SAS Institute, Cary NC.

Sevim, B., Olgun, O., Şentürk, E.T., Yıldız, A.Ö., 2020. The effect of orange peel oil addition to laying quail diets on performance, eggshell quality and some serum parameters. Turkish Journal of Agriculture - Food Science and Technology, 8(8): 1773-1777.

Sharmin, T., Ahmed, N., Hossain, A., Hosain, M.M., Mondal, S.C., Haque, R., Almas, M., Sıddık, A.B., 2016. Extraction of bioactive compound from some fruits and vegetables (pomegranate peel, carrot and tomato). American Journal of Food and Nutrition 4(1): 8-19.

Syed, D.N., Afaq, F., Mukhtar, H., 2007. Pomegranate derived products for cancer chemoprevention. Semin Cancer Biol. 17: 377-385.

Ting, S., Yeh, H.S., Lien, T.F., 2011. Effects of supplemental levels of hesperetin and naringenin on egg quality, serum traits and antioxidant activity of laying hens. Animal Feed Science and Technology 163: $59-66$.

Turhan, İ., Tetik, N., Karhan, M., 2006. Turunçgil kabuk yağlarının elde edilmesi ve gıda endüstrisinde kullanımı Gıda Teknolojileri Elektronik Dergisi 3: 7177.

Yaman, K., 2012. Bitkisel atıkların değerlendirilmesi ve ekonomik önemi. Kastamonu Üniversitesi Orman Fakültesi Dergisi 12(2): 339-348.

Yassein, D.M.M., Abdallah, E.A., Ismail, I.I., Faddle, A.A., 2015. Effect of dietary supplementation of pomegranate peel powder and butylated hydroxy toluene on some productive, physiological and immunological parameters of Japanese quail. Egyptian Society Journal of Animal Production 52: 105-113 